\title{
Image processing of periapical radiograph on granuloma detection by analysis method based on Android
}

\author{
Merry Annisa Damayanti ${ }^{*}$, Suhardjo Sitam ${ }^{1}$, \\ Bambang Hidayat ${ }^{2}$, Ivhatry Rizky Octavia Putri Susilo
}

\begin{abstract}
Objectives: The study assesses periapical radiograph image with various android based analysis method to detect granuloma.

Materials and Methods: The study uses survey descriptive cross sectional by using questionnaire. The questionnaire is distributed to 70 random respondents. The methods of the android application used are BLOB (Binary Large Object), DCT and LDA (Discrete Cosine Transform and Linier Discriminant Analysis), DWT and PCA (Discrete Wavelet Transform \& Principal Component Analysis), and multiwavelet transformation. The questionnaire assessment included accuracy, effectiveness, attractiveness, innovativeness of the android application.
\end{abstract}

Results: Android application with BLOB has effectivity and accuracy of $62,5 \%$, attractiveness and innovativeness of $75 \%$. Android application with DCT and LDA has effectivity and accuracy of $50 \%$, attractiveness of $70 \%$ and innovativeness of $80 \%$. Android application with DWT and PCA has effectivity of $50 \%$, accuracy of $60 \%$, attractiveness of $66,66 \%$ and innovativeness of $80 \%$. Android application with multiwavelet transformation has effectivity and accuracy of $50 \%$, attractiveness of $55 \%$ and innovativeness of $73 \%$.

Conclusion: Based on assessment, the four methods used to detect granuloma are effective and applicative with android-based application. Android-based Application can detect granuloma with approximately more than $70 \%$ successful rate. These methods ease the practitioner to interpret the granuloma image.

Keywords: Periapical radiograph, granuloma, android-based application

Cite this article: Damayanti MA, Sitam S, Hidayat B, Susilo IROP. Image processing of periapical radiograph on granuloma detection by analysis method based on Android. Jurnal Radiologi Dentomaksilofasial Indonesia 2021;5(1)1-6. https://doi.org/10.32793/jrdi.v5i1.672

\section{INTRODUCTION}

Practitioners use of periapical radiographs to see the condition of dental and surrounding tissue were accurate. ${ }^{3}$ However, the interpretation of a radiographic image by dentists and radiologists is still limited. Thus, the supporting tools for periapical radiograph haven't been well distributed to al region in Indonesia, especially rural and remote areas because of the machine is big and expensive. Advancing technology gives more accuracy interpret in medical treatment.

Granuloma is growing granulomatous tissue which is correlated with periodontal ligament caused by necrotic pulp, bacterial fusion and bacterial toxin from surrounding tissue through apical foramen and lateral canal. ${ }^{1,2}$ Granuloma radiographic image has a radiolucent with clear borderline or diffuse on periapical, with vary size, round shape, lamina dura missing which may involve the bone condensation and root resorption won't occur. ${ }^{2}$

Android-based application is expressed to be able to diagnose granuloma. Android is Linux-based system which created for touchscreen cellular device as smartphone and tablet computer. Android has a community applicate-development expanding device functional, generally is created by costumed version java-based program. Android may use to installed third application that obtainable in Google Play and Amazon. In Google Play Store, Users can explore, download and update application published in google and developed with third users in appropriate capability Google term. ${ }^{5}$

Android-based application varies method including BLOB method, DCT and PCA method, Multiwavelet method and DCT and LDA method. BLOB method is the one of methods image segmenting to analyze more specific and accurate by differentiating color. BLOB uses to isolate bright objects from the background and unites them into one region. ${ }^{15}$ The previous research Gemintang (2016) with BLOB shows an accuracy of approximately $80 \%{ }^{9}$

According to Wijayanti (2016), Android-based application with DWT \& PCA method shows an accuracy of approximately $90 \%$. DWT is form conversion from signal imaging which doesn't the 
information in a different time. Wavelet transform form gives information of frequency, scale and duration. ${ }^{14}$ PCA is a linier-reduction technic using a similar theory from statistics. PCA is use to extract image features where the number of image dimension is more than that of samples used. ${ }^{8}$

Multiwavelet transformation is development form of the wavelet transformation. The basic theory of multiwavelet is multiresolution analyze (MRA). The wavelet transformation consists of one scaling and one wavelet function, whereas in multiwavelet consist of several scaling function and wavelet function. ${ }^{15,16}$ The study according to Damanik (2016) shows accuracy approximately $90 \% .{ }^{11}$

According to Buana (2016), DCT and LDA method shows a maximum accuracy $85 \%$. DCT is one of the significant transformations on digital image processing. It interprets image from sinusoidal combination from magnitude and frequency change. LDA is one of the methods which uses statistic. It is a pattern recognitions method to find linier combination of features to be characterized to separate greater than or equal to two objects. ${ }^{12}$ Based on these studies with a good accuracy, effectiveness of android-based application for granuloma detection needs to be assessed.

\section{MATERIALS AND METHODS}

This study uses periapical conventional radiographs of male and female patients on productive age between 20-70 years old that came into Radiology Department, Padjadjaran University Dental Hospital. The photos were inputted into application by using a Canon scanner (CanoScan 9000 F Mark II) under jpg. format. The photos used are normal and granuloma teeth photos that were manually cropped at the periapical area, converted into HSV format and resized. This study uses four Android-based methods: Binary Large Object (BLOB); Discrete Wavelet Transform (DWT) and Principal Component Analysis (PCA); Multiwavelet Transformation type Geronimo-Hardin-Massopust (GHM); and Discrete Cosine Transform (DCT) and Linier Discriminant Analysis (LDA).

\section{Binary Large Object (BLOB) Method}

An android-based mobile device to run the simulation program is Android 5.1.1 Lollipop-A53 Quad-core $1.2 \mathrm{GHz}$ Cortex with 13 Megapixel camera (Figure 1 and 2). Periapical radiology photo images used are 18 granuloma photo data and 18 normal photo data. These photo data are paired randomly, resized to $256 \times 256$ pixels, and converted to HSV.Granuloma detection analysis is executed on the offline android studio by using programming languages Matlab R2015a software (version 8.5.0).

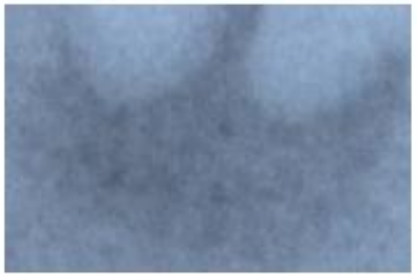

(A)

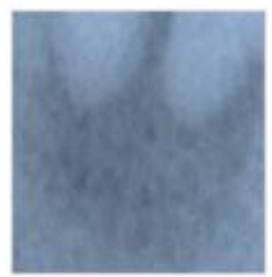

(B)

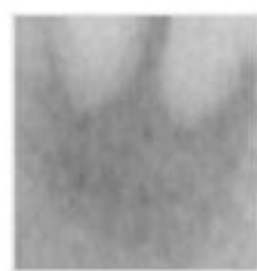

(C)

Figure 1. (A) Result of cropping, (B) Result of resize, and (C) Result of conversion HSV.

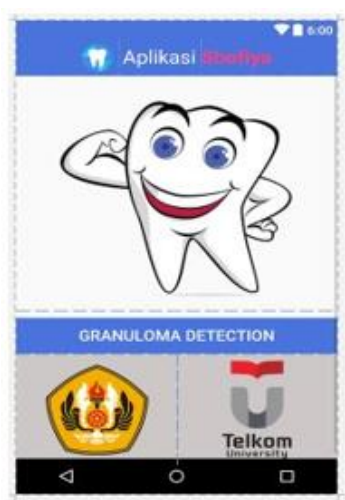

(A)

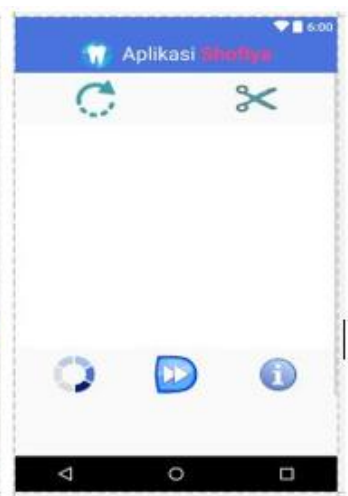

(B)

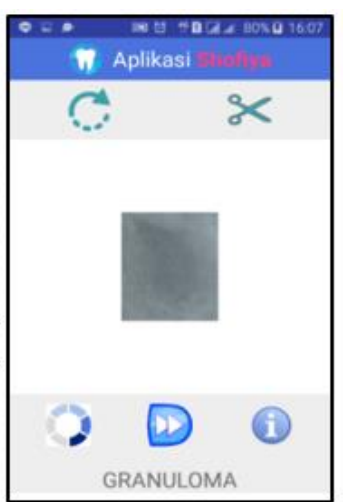

(C)

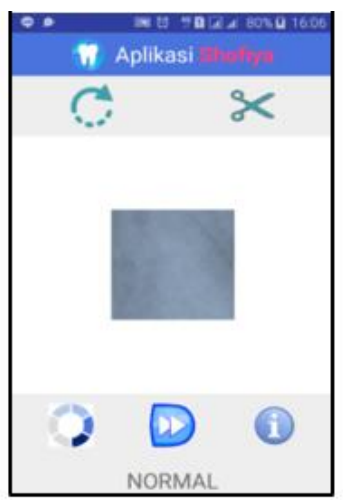

(D)

Figure 2. (A) System layout, (B) Home layout (C) Normal teeth image data, (D) Granuloma teeth image data. 
Discrete Cosine Transform (DCT) and Linier Discriminant Analysis (LDA) Method

An Android-based mobile device to run the simulation program is 4.4.2 Kitkat Mediatek MT6592 Octa-core $1,7 \mathrm{GHz}$ with 13 Megapixels camera (Figure 3 and 4). Periapical photos used are 8 normal photos and 8 granuloma photos. These photos are entered to the pre-processing stage. In this stage, the photos are resized into $128 \times 128$ pixels and then cropped at the tooth root Furthermore, the image is converted from RGB into Grayscale format.

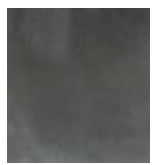

Figure 3. Cropped Image Photo

Discrete Wavelet Transform (DWT) and Principal Component Analysis (PCA) Method

An Android-based mobile device to run the simulation program is Android $^{\mathrm{TM}}$ 6.0.1
Marshmallow (Figure 5 and 6). Periapical radiology photo images used are 8 granuloma photo data and 8 normal photo data. These photo data are paired randomly. These photos are used as input photo data to be processed into the system. Each cropped photo leaving only the teeth were diagnosed with granuloma disease. To simplify the process of granuloma disease detection, a periapical radiograph photo should be rotated with the root is positioned at the bottom and the crown is positioned on top. Next, photos are resized.

Multiwavelet Transformation type GeronimoHardin-Massopust (GHM) Method.

An Android-based mobile device to run the simulation program is Android 4.4.2 Kitkat A74D Evercross model with 8 Megapixel camera (Figure 7 and 8). Periapical photos image used are 8 normal photos and 8 granuloma photos. These photo data are paired randomly. These photos are used as input photo data to be processed into the system. Digital photos are resized then changed from RGB into grayscale resulting in pre-processing image.

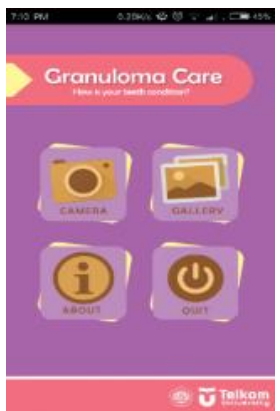

(A)

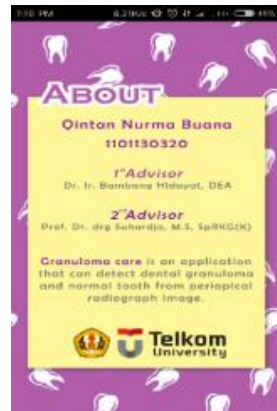

(B)

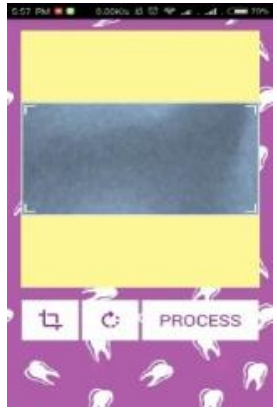

(C)

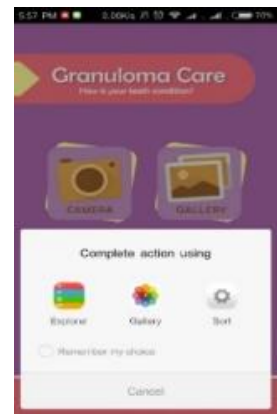

(D)

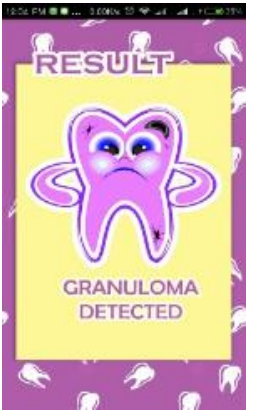

(E)

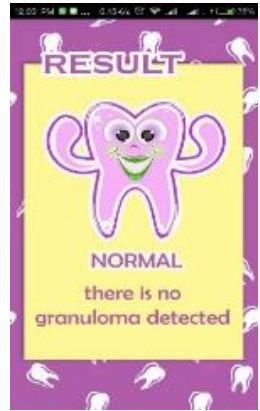

(F)

Figure 4. (A) Home Layout, (B) ‘About' Layout, (C) ‘Option' Layout, (D) Process Layout, (E) Normal Layout, (F) Granuloma layout.

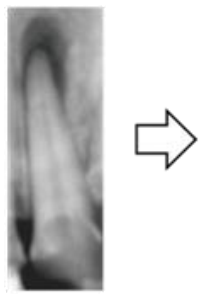

(a)

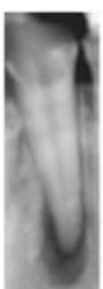

(b)

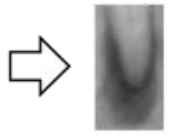

(c)

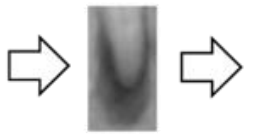

(d)

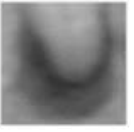

(e)

Figure 5. a) Diagnosed Granuloma image, (b) Result of rotated image, (c) Cropped Granuloma Periapical image, (d) Result of Grayscale image, (e) Resized image.

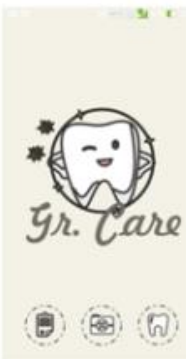

(A)

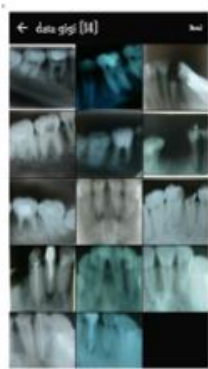

(B)

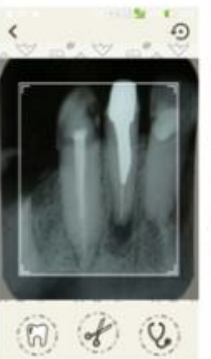

(C)

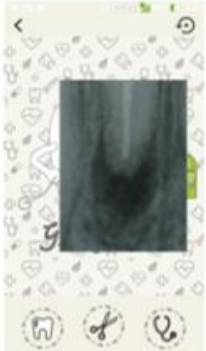

(D)

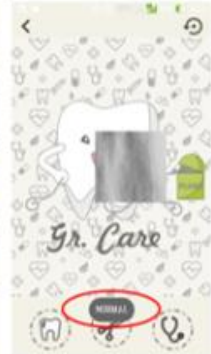

(E)

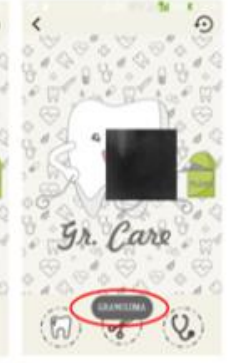

(F)

Figure 6. (A) System layout, (B) Home layout, (C) Teeth image data, (D) Resized image data, (E) Normal layout, (F) Granuloma layout. 


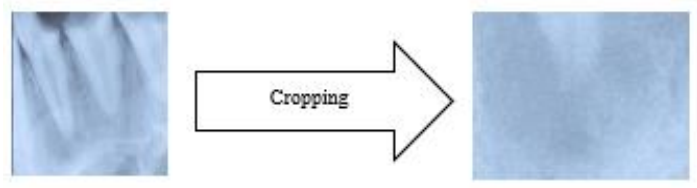

Figure 7. RGB image into Grayscale image

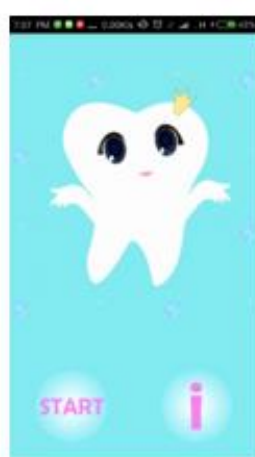

(A)

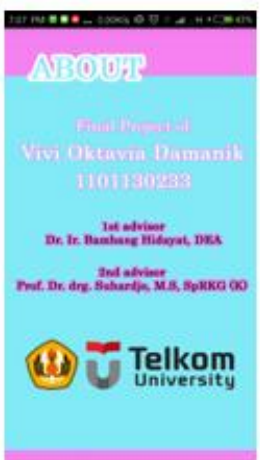

(B)

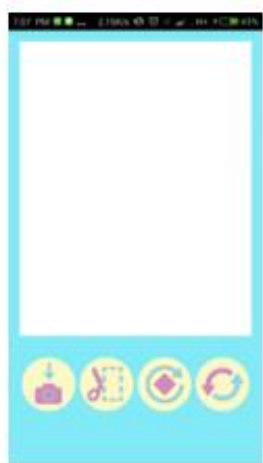

(C)

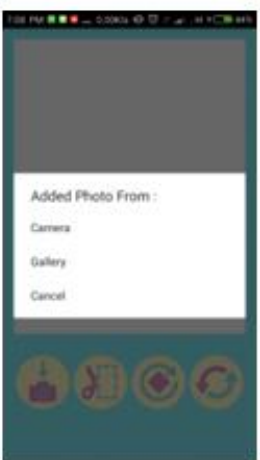

(D)

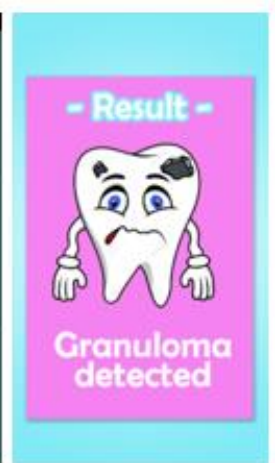

(E)

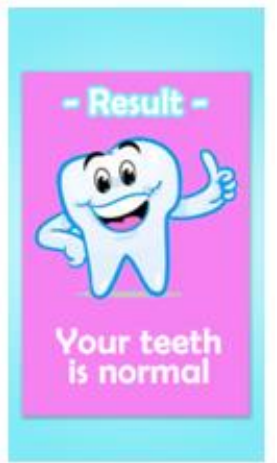

(F)

Figure 8. (A) Home Layout, (B) 'About' Layout, (C) 'Option' Layout, (D) Process Layout. Result layout showing (E) Normal Layout, (F) Granuloma layout.

After inserting the photos, questionnaire is distributed to 70 peoples of co-assistant and dentists, and images are assessed in Oral and Maxillofacial Hospital, Padjadjaran University.

\section{RESULTS}

The aim of this study is to measure the android application to users. The questionnaire is given to given to 70 respondent including co-assistant and dentist, in Dentistry Faculty, Padjajaran University. The questionnaire assessment included accuracy, effectiveness, attractiveness, innovativeness of the android application.

Figure 9 shows assessment-chart Android-based application method using BLOB, DCT and LDA, DWT and PCA, and Multiwavelet. In BLOB method, the percentage of application accuracy and effectiveness shown by $62,5 \%$. The BLOBapplication has an attractiveness as shown by $75 \%$. It hasn't used before (innovativeness) shown by $75 \%$.

Testing DCT and LDA method application quietly helpful for assessing to diagnose granuloma (attractive and accuracy) as shown by $50 \%$. It's quietly effective (effectivity) as shown by $50 \%$. It has an attractive view and helpful (innovativeness) as shown by $70 \%$. It hasn't used before and it shown by $80 \%$.

Testing DWT and PCA method application quietly helpful for assessing to diagnose granuloma as shown by $50 \%$. It's quietly effective and simple uses as shown by $60 \%$. It has an attractive view and helpful as shown by $66,66 \%$. It hasn't used before and it shown by $80 \%$.

The last method is multiwavelet method application. This method application quietly helpful for assessing to diagnose granuloma as shown by

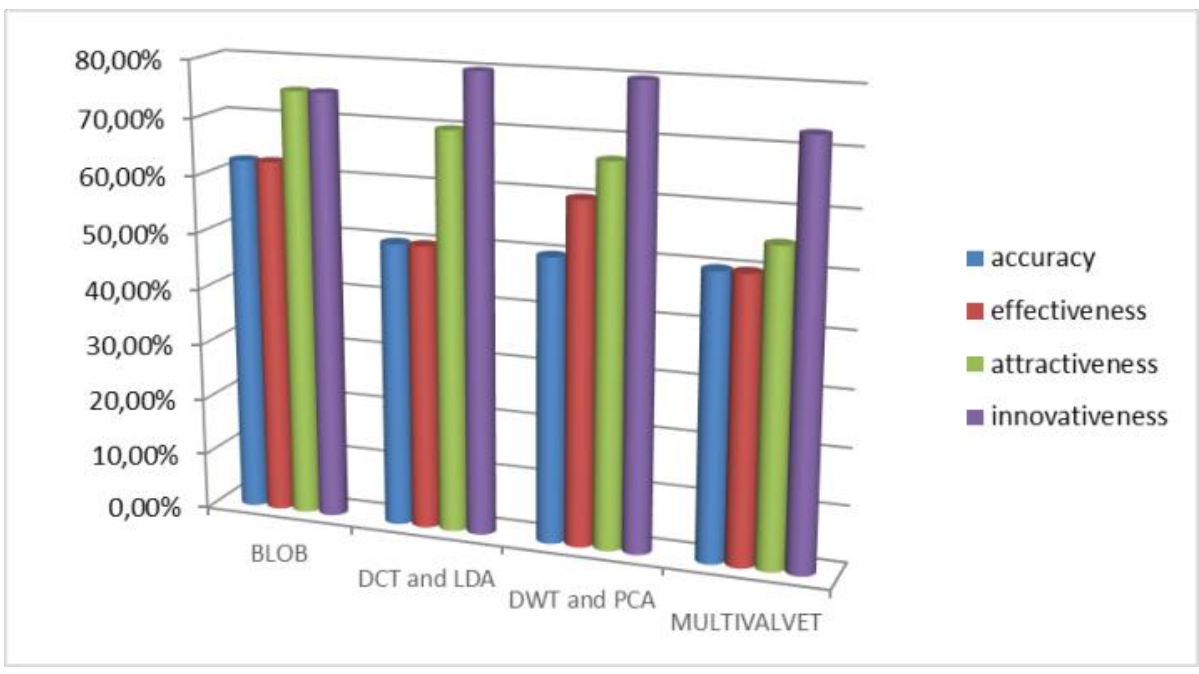

Figure 9. Assessment-chart Android-based application method 
Table 1. Questionnaire of granuloma detection periapical radiograph in Android-based application method

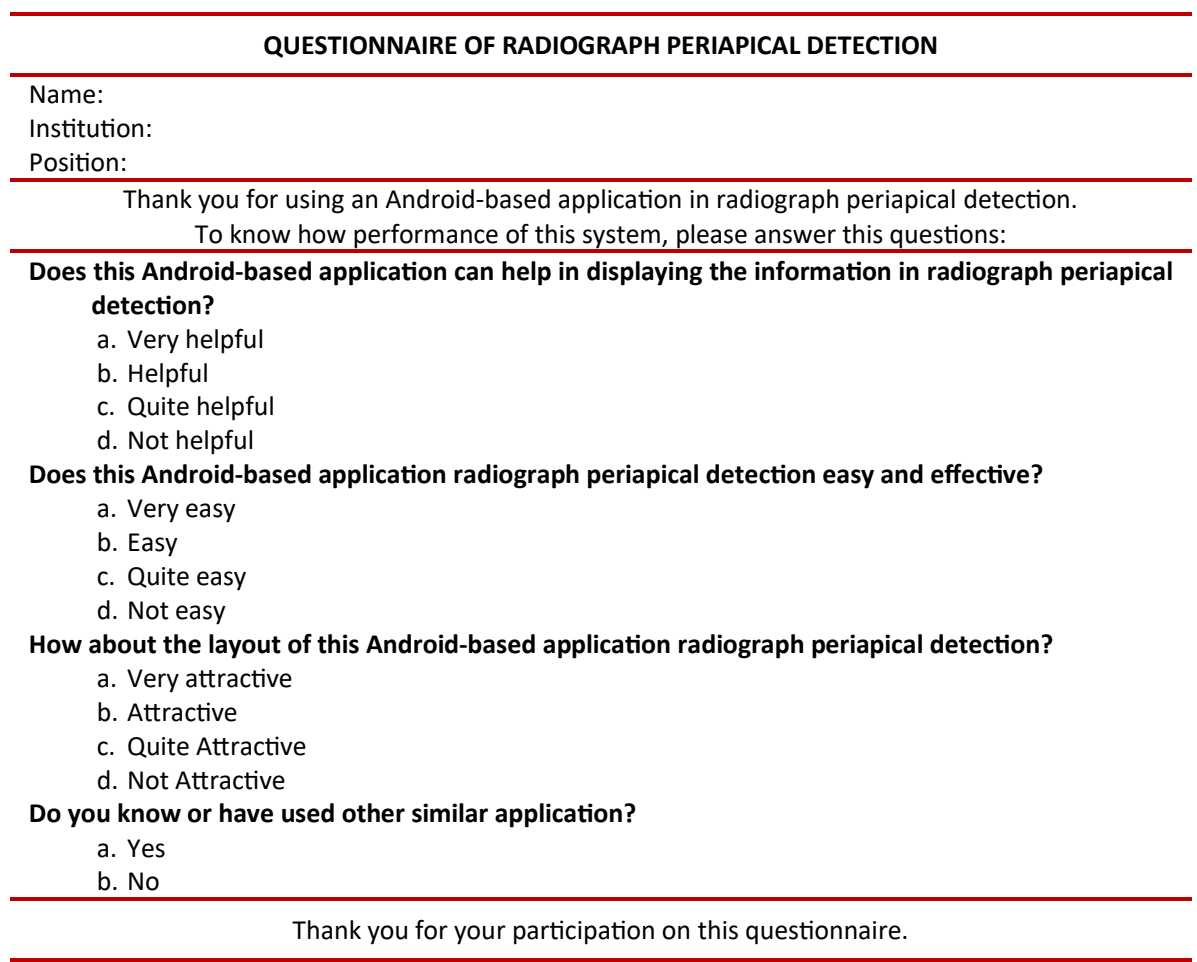

$50 \%$. It's quietly effective and simple uses as shown by $50 \%$. It has an attractive view and helpfu as shown by $55 \%$. It hasn't used before and it shown by $73 \%$.

\section{DISCUSSION}

Decision to interpret a diagnostic imaging should be based on patient needs. Diagnostic image refers not only to conventional radiograph but also to any digital radiograph as an output $X$-ray. Patient's need of dental radiograph imaging is determined by dental medical record and clinical examination findings related to age and general health condition. Diagnostic imaging is needed when dental medical record and clinical examination cannot give enough information for comprehensive evaluation of patient condition and for appropriate management.

Image quality describes the subjective judgment by the clinician of the overall appearance of a radiograph. It combines the features of density, contrast, latitude, sharpness, resolution, and other parameters. Various mathematic approaches are used to further evaluate these parameters, thoroughly. Density is a degree of darkness of a radiographic film. The density of tissue irradiated with X-rays affect black area density on the radiographic film. These terms used to indicate density of black films, showing radiographs photographic film which has been developed and expressed by the logarithm opaque zone that depends on film. In this study, assessing androidbased application on detect periapical photo normal teeth and granuloma. Each of method has advantages and disadvantages.

The first method is BLOB. The advantages of BLOB are isolating and detecting an object from the dots pixel having a brightness of the background color and incorporating them into a part. BLOB classifying a pixel with another pixel is almost similar uses the concept of neighborhood and labeling then separate into a part. Approaching use to analyze the texture of an area, (statistical and structural). Statistical approach considering intensity is raised and based on the frequencies of space (spatial) and produces characteristic texture as smooth, rough, and others. While structural engineering related to the preparation of the smallest parts (primitive) of an image.

DCT and LDA methods have contras level, structure and color better because of histogram equalization (technique to get a new image that is grayscale image with the range of contras $0-225)$. DCT method describe spatial information to describing the shape of object roughly, therefore LDA method is needed to classify an object in a linear manner to one of the two or more groups.

DWT and PCA method have a high accuracy rate. This method combines decomposition image on a certain level of decomposition, which in this level of decomposition was process through high pass filter and low pass filter signal with a linear reduction technique using simple theories of statistics. With this PCA method, the changes occur in feature extraction based on "appearance", where the dimensions of the image are bigger than the amount of sample data that been used.

Multiwavelet transformation method also has a high accuracy rate. This method using two scaling function and two wavelet functions in the image. The accuracy of this method is affected by the 
magnitude of the image pixel input and computation time. The larger image size, the accuracy of the system is declining, and more time to takes the system to perform processing on the image.

Through Android system, respondents judge about the usefulness of the information display, effective and accuracy, attractiveness and innovativeness system. The system that can helpful on view displays system of effective and accuracy is DCT and LDA system and multiwavelet system. The useless method is DWT and PCA. A View display simulation, all system is attractive except DWT and PCA system. Neither Multiwavelet is innovative because it hasn't use it before nor DCA and LDA system.

\section{CONCLUSION}

From the assessment, it can be concluded that Android-based analysis method is successful in detecting granuloma on periapical radiograph Android-based Application can detect granuloma with approximately more than $70 \%$ successful rate. The granuloma detection with the fourth method is effective and applicative so practitioners can interpret easily.

\section{ACKNOWLEDGMENTS}

None.

\section{FOOTNOTES}

All authors have no potential conflict of interest to declare for this article. This article does not contain any studies with human or animal subjects performed by the any of the authors.

\section{REFERENCES}

1. White SC, Pharoah MJ. Oral Radiology: Principles and Interpretation. 6th ed. St.Louis: Mosby; 2009.

2. Thomas A, Firman RN, Azhari A. Analisis radiograf periapikal menggunakan software ImageJ pada granuloma periapikal pada perawatan endodontik. Maj Kedokt Gigi Indones. 2017;3 (2):105-10.

3. Margono G. Radiografi Periapikal Untuk Mendukung Perawatan Dalam Kedokteran Gigi. Jurnal PDGI Edisi Khusus Tahun ke-52. Jakarta: Fakultas Kedokteran Gigi Usakti; 2002.

4. Grossman LI, Oliet S, Del Rio CE. IImu Endodontik dalam Praktek, 11th ed., Prof. drg Sutatmi Suryo, Ed. Jakarta: Perpustakaan Nasional; 1995.

5. Garg N, Garg A. Textbook of Endodontics. New Delhi: Ajanta Offset \& Packagings Ltd.; 2007. p. 41

6. Sitam S. Radiografi Periapikal. EGC; 2013

7. Shridar B, Prasad DV. Finding 3D Teeth Positions by Using 2D Uncalibrated Dental X-Ray Images. Blenkinge Institute of Technology; 2010.

8. Kadir A, Susanto A. Teori dan Aplikasi Pengolahan Citra. Yogyakarta: ANDI, 2013.

9. Amalina N. Simulasi Matlab pada Deteksi Penyakit Gigi Granuloma Menggunakan Principal Component Analysis dan STransform Melalui Radiograf Periapikal dengan Metoda Radial Basis Function. Bandung: Universitas Telkom; 2014.

10. Utami NP. Deteksi Granuloma melalui Citra Periapikal Radiograf dengan Menggunakan Metode K-NN (K-Nearest Neighbour) pada Aplikasi Android (Skripsi). Bandung: Universitas Telkom; 2014

11. Annisa A. Simulasi dan Analisis Deteksi Abses Periapikal Menggunakan Transformasi DWT (Discrete Wavelet Transform) dan metode PCA (Principal Component Analysis). Bandung: Universitas Telkom; 2014.

12. Gemintang RS, Hidayat $B$, Sitam S. Pengolahan Citra Radiograf Periapikal pada Deteksi Penyakit Granuloma dengan Metode Binary Large Object Berbasis Android. e-Proceeding of Engineering 2017;4(1):106-14

13. Wijayanti LA, Hidayat B, Sitam S. Pengolahan Citra Radiograf Periapikal Pada Deteksi Penyakit Granuloma Menggunakan Metode Discrete Wavelet Transform \& Principal Component Analysis Berbasis Android. e-Proceeding of Engineering 2017;4 (1):333-9.

14. Damanik VO, Hidayat B, Sitam S. Pengolahan Citra Radiograf Periapikal Pada Deteksi Penyakit Granuloma Dengan Metode Multiwavelet Berbasis Android. e-Proceeding of Engineering 2017;4(1):547-54

15. Buana QN, Hidayat B, Sitam S. Pengolahan Citra Deteksi Granuloma Melalui Periapical Radiograf Dengan Metode Transformasi Dct Dan Linier Discriminant Analysis Berbasis Android. e-Proceeding of Engineering 2017;4(1):367-71.

16. MATLAB Image Processing Toolbox User Guide. The Math Works Inc. 2002

17. Zardi A. Klasifikasi Kanker Usus Besar Berdasarkan Analisis Tekstur Dengan Deteksi Binary Large Object (BLOB). Bandung: Universitas Telkom; 2015.

18. Bala E, Ertuzun A. Applications of Multiwavelet Techniques to Image Denoising. IEEE 2002;3:581-4.

19. Strela V, Heller PN, Strang G, Topiwala P, Heil C. The Application of Multiwavelet Filter Banks to Image Processing. IEEE 1999;8(4):548-63. 